Article

\title{
Synthesis, Characterization and Antibacterial Studies of $N$-(Benzothiazol-2-yl)-4-chlorobenzenesulphonamide and Its Neodymium(III) and Thallium(III) Complexes
}

\author{
Lawrence Nnamdi Obasi ${ }^{1}$, Uchechukwu Susan Oruma ${ }^{1, *}$, Ibrahim Abdulrazak Al-Swaidan ${ }^{2}$, \\ Ponnadurai Ramasami ${ }^{3,4}$, Chigozie Julius Ezeorah ${ }^{1}$ and Alfred Ezinna Ochonogor ${ }^{1}$ \\ 1 Department of Pure and Industrial Chemistry, University of Nigeria, Nsukka 410001, Nigeria; \\ nnamdi.obasi@unn.edu.ng (L.N.O.); chigozie.ezeorah@unn.edu.ng (C.J.E.); \\ alfred.ochonogor@unn.edu.ng (A.E.O.) \\ 2 Department of Pharmaceutical Chemistry, College of Pharmacy, King Saud University, P.O. Box 2457, \\ Riyadh 11451, Saudi Arabia; ialsuwidan@ksu.edu.sa \\ 3 Computational Chemistry Group, Department of Chemistry, Faculty of Science, University of Mauritius, \\ Réduit 80837, Mauritius; ramchemi@intnet.mu \\ 4 Department of Applied Chemistry, University of Johannesburg, Doornfontein Campus, \\ Johannesburg 2028, South Africa \\ * Correspondence: susan.oruma@unn.edu.ng; Tel.: +234-806-122-2297
}

Academic Editors: Panayiotis A. Koutentis and Andreas S. Kalogirou

Received: 9 November 2016; Accepted: 4 January 2017; Published: 22 February 2017

\begin{abstract}
N-(Benzothiazol-2-yl)-4-chlorobenzenesulphonamide (NBTCS) was synthesized by condensation reaction of 4-chlorobenzenesulphonyl chloride and 2-aminobenzothiazole in acetone under reflux. Neodymium(III) and thallium(III) complexes of the ligand were also synthesized. Both ligand and metal complexes were characterized using UV-Vis, $\mathrm{IR},{ }^{1} \mathrm{H}$ - and ${ }^{13} \mathrm{C}-\mathrm{NMR}$ spectroscopies, elemental analysis and molar conductance measurement. IR studies revealed that the ligand is tridentate and coordinates to the metal ions through nitrogen and oxygen atoms of the sulphonamide group and nitrogen atom attached to benzothiazole ring. The neodymium(III) complex displays a coordination number of eight while thallium(III) complex displays a coordination number of six. The ligand and its complexes were screened in vitro for their antibacterial activities against Escherichia coli strains (E. coli 6 and E. coli 13), Proteus species, Staphylococcus aureus and Pseudomonas aeruginosa using the agar well diffusion technique. The synthesized compounds were found to be more active against the microorganisms screened relative to ciprofloxacin, gentamicin and co-trimoxazole.
\end{abstract}

Keywords: N-(benzothiazol-2-yl)-4-chlorobenzenesulphonamide; neodymium(III) and thallium(III) complexes; antibacterial activity

\section{Introduction}

Sulpha drugs, also known as sulphonamides, are compounds, which have a general structure represented by Figure 1. Sulpha drugs were discovered in 1930s during a series of studies with a bright red dye named prontosil $[1,2]$. Prontosil was found to be able to cure severe staphylococcal septicemia in human [2]. After the discovery of prontosil, several drugs containing the sulphonamide moiety have been prepared and put into diverse medical applications. They serve as antimicrobial drugs (sulphacetamide) [3-5]; diuretic drugs (acetazolamide) [6]; anticonvulsants (sultiame) [6]; dermatological drugs (mafenide) [7]; anticancer [8-10]; anti-inflammatory [11,12]; antihypertensive agent (bosentan) [13] and antiviral agents; and HIV protease inhibitors [14,15]. Their antimicrobial activities arise due to competitive inhibition of the enzyme dihydropteroatesynthetase (DHPS), an enzyme involved in folate synthesis. As such, the microorganism will be starved of folate and die. 
The similarity of the structure between sulphonamide and $p$-aminobenzoic acid (PABA), a molecule found in bacteria used in folic acid synthesis, is the basis for the inhibitory activity of sulpha drugs on dihydrofolate biosynthesis $[1,6,16]$. Sulpha drugs are associated with antibiotic resistance and allergies [17,18]. The work done by Yun et al. 2012 gave insight into sulpha drug resistance [1]. They revealed that the binding sites of PABA and sulpha drugs overlap, but those of sulpha drugs extend beyond the pocket in which PABA binds. Mutations associated with drug resistance cluster around this extended region of the PABA pocket. This explains how they can prevent the drugs from binding without seriously affecting the binding of PABA. Several modifications have been made on the general structure of sulphonamides, resulting in new compounds with varying pharmacological activities and reduced side effect [2]. The work done by Lawrence et al. 2010 have shown that the best therapeutic results were obtained from the compounds in which one hydrogen atom of the $\mathrm{SO}_{2} \mathrm{NH}_{2}$ group was replaced by heterocyclic ring [19]. Previous studies by Obasi et al. have led to discovery of ligands and complexes with varying activities against multi-resistant bacterial strains isolated under clinical conditions and cultured species using agar-well diffusion method [20-22]. Metal complexes of sulpha drugs have been reported with appreciable biological activities [23-28]. Recently, there have been several reports on neodymium(III) and thallium(III) complexes [29-37]. Mimouni et al., 2014 [38] have synthesized, characterized, and studied the antibacterial, antifungal and antitubercular activities of thallium complexes of monensin and lasalocid. Their study revealed that remarkable bioactivity against different pathogens were achieved and confirmed that the compounds could very likely be used without great risk of toxicity in diverse pharmaceutical applications. In addition, the crystal structures of thallium salt of Grisorixin and antibiotic 6016 thallium salt have been reported [39,40]. In view of the need for a new generation of antibiotics that would cause fewer side effects, we designed a new class of inhibitors namely: $N$-(benzothiazol-2-yl)-4-chlorobenzenesulphonamide (NBTCS) and its neodymium(III), and thallium(III) complexes. Their in vitro antibacterial activities against Escherichia coli strains (E. coli 6 and E. coli 13), Proteus species, Staphylococcus aureus and Pseudomonas aeruginosa were also investigated.

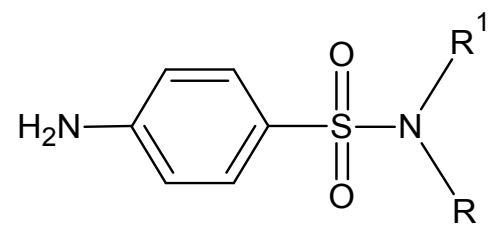

Figure 1. General structure of sulphonamides; $\mathrm{R}=\mathrm{R} 1=\mathrm{H}$ for sulphanilamide.

\section{Results and Discussion}

The reaction of 2-aminobenzothiazole with 4-chlorobenzenesulphonylchloride yielded $\mathrm{N}$-(benzothiazol-2-yl)-4-chlorobenzenesulphonamide (NBTCS) as shown in Scheme 1. The reaction of $\mathrm{Nd}\left(\mathrm{NO}_{3}\right)_{3} \cdot 5 \mathrm{H}_{2} \mathrm{O}$ and $\mathrm{C}_{6} \mathrm{H}_{9} \mathrm{O}_{6} \mathrm{Tl}$ with NBTCS yielded $\left[\mathrm{Nd}(\mathrm{NBTCS})_{2}\left(\mathrm{H}_{2} \mathrm{O}\right)_{2}\right] \mathrm{NO}_{3}$ and [Tl(NBTCS) $\left.)_{2}\right] \mathrm{CH}_{3} \mathrm{COO}$, respectively. The ligand and complexes are air stable and have high melting points. They are soluble in ethanol, methanol, acetic acid and DMSO. The analytical data of NBTCS and its complexes are shown in Table 1. The elemental analysis of the NBTCS and its complexes show that the amount of carbon, hydrogen, nitrogen and sulphur (CHNS) are close to the experimentally determined values. The values of molar conductance of the complexes in DMSO at room temperature were found to be $72 \Omega^{-1} \cdot \mathrm{cm}^{2} \cdot \mathrm{mol}^{-1}$ and $88 \Omega^{-1} \cdot \mathrm{cm}^{2} \cdot \mathrm{mol}^{-1}$ for the $\mathrm{Nd}(\mathrm{III})$ and Tl(III) complexes, respectively. These values indicate 1:1 electrolytic nature of the complexes [41]. The ligand was found to be non-electrolyte with a molar conductance value of $15.6 \Omega^{-1} \cdot \mathrm{cm}^{2} \cdot \mathrm{mol}^{-1}$. 
<smiles>Nc1nc2ccccc2s1</smiles>

2-aminobenzothiazole

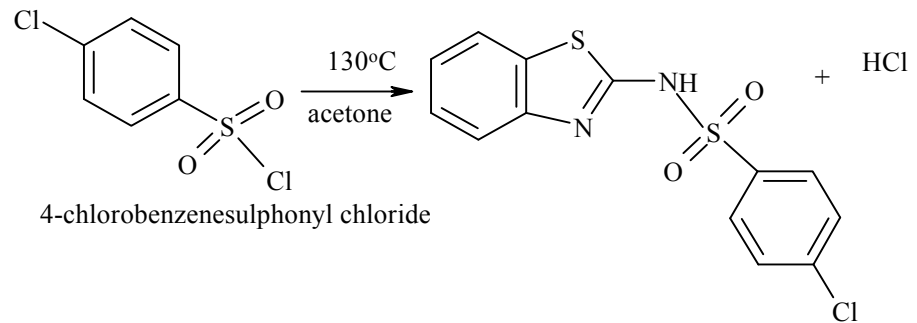

N-(benzothiazol-2-yl)-4-chlorobenzenesulfonamide

Scheme 1. Synthesis of N-(benzothiazol-2-yl)-4-chlorobenzenesulphonamide.

Table 1. Physical properties and elemental analysis of N-(Benzothiazol-2-yl)-4-chlorobenzenesulphonamide (NBTCS) and its complexes.

\begin{tabular}{|c|c|c|c|c|c|c|c|c|}
\hline \multirow{2}{*}{ Compound } & \multirow{2}{*}{$\begin{array}{l}\text { Molar Weight } \\
(\mathrm{g} / \mathrm{mol})\end{array}$} & \multicolumn{4}{|c|}{ Cal. (Exp., \%) } & \multirow{2}{*}{$\begin{array}{l}\text { Molar Cond. } \\
\left(\Omega^{-1} \cdot \mathrm{cm}^{2} \cdot \mathrm{mol}^{-1}\right)\end{array}$} & \multirow{2}{*}{ Colour } & \multirow{2}{*}{ Yield (\%) } \\
\hline & & $\mathrm{C}$ & $\mathbf{H}$ & $\mathbf{N}$ & $\mathrm{S}$ & & & \\
\hline NBTCS & 324.5 & $\begin{array}{c}48.07 \\
(48.11)\end{array}$ & $\begin{array}{c}2.77 \\
(2.94)\end{array}$ & $\begin{array}{c}8.63 \\
(8.75)\end{array}$ & $\begin{array}{c}19.72 \\
(19.89)\end{array}$ & 15.6 & White & 40.83 \\
\hline$\left[\mathrm{Nd}(\mathrm{NBTCS})_{2}\left(\mathrm{H}_{2} \mathrm{O}\right)_{2}\right] \mathrm{NO}_{3}$ & 891 & $\begin{array}{c}35.02 \\
(34.99)\end{array}$ & $\begin{array}{c}2.47 \\
(2.36)\end{array}$ & $\begin{array}{c}7.86 \\
(7.60)\end{array}$ & $\begin{array}{c}14.37 \\
(14.20)\end{array}$ & 72 & Yellow & 32.24 \\
\hline$\left[\mathrm{Tl}(\mathrm{NBTCS})_{2}\right] \mathrm{CH}_{3} \mathrm{COO}$ & 912 & $\begin{array}{c}36.84 \\
(36.40)\end{array}$ & $\begin{array}{c}2.30 \\
(2.80)\end{array}$ & $\begin{array}{c}6.14 \\
(6.07)\end{array}$ & $\begin{array}{c}14.04 \\
(13.96)\end{array}$ & 88 & Brown & 34.97 \\
\hline
\end{tabular}

\subsection{Electronic Spectra}

Electronic absorption spectra of the ligand and complexes in ethanol were recorded in the range 200-700 $\mathrm{nm}$ and the results are presented in Table 2. The electronic absorption spectra of the compounds show absorption bands between 230 and $282 \mathrm{~nm}$, assigned to $\pi-\pi^{*}$ transitions. The band at $305 \mathrm{~nm}$ is attributed to $n-\pi^{*}$ transition from conjugation between the lone pair of electrons on p-orbital of nitrogen atom and conjugated $\pi$-bond of the benzene ring [42]. In the complexes, blue shifts were observed in the $\pi-\pi^{*}$ transition which could be as a result of removal of lone pair of electron on the electronegative atoms of the ligand upon coordination [43]. The $\mathrm{Nd}$ (III) complex did not contribute appreciably to the electronic spectra since for lanthanide ions $\mathrm{f}-\mathrm{f}$ transitions are Larporte-forbidden and weak in nature.

Table 2. UV-Vis spectral data $\lambda_{\max }(\mathrm{nm})$ of NBTCS and complexes.

\begin{tabular}{ccccc}
\hline Compound & $\lambda_{\max }(\mathbf{n m})$ & $\tilde{v}\left(\mathbf{c m}^{-\mathbf{1}}\right)$ & $\varepsilon\left(\mathbf{L}^{\prime} \mathbf{m o l}^{-1} \cdot \mathbf{c m}^{-\mathbf{1}}\right)$ & Assignment \\
\hline \multirow{2}{*}{$\mathrm{NBTCS}$} & 272,282 & $29,239,30,314$ & 6925,6860 & $\pi-\pi^{*}$ \\
& 305 & 32,787 & 7363 & $\mathrm{n}-\pi^{*}$ \\
\hline$\left[\mathrm{Nd}(\mathrm{NBTCS})_{2}\left(\mathrm{H}_{2} \mathrm{O}\right)_{2}\right] \mathrm{NO}_{3}$ & $230,237,250$ & $24,725,25,477,26,875$ & $8237,8333,8333$ & $\pi-\pi^{*}$ \\
{$\left[\mathrm{Tl}(\mathrm{NBTCS})_{2}\right] \mathrm{CH}_{3} \mathrm{COO}$} & $241,248,261$ & $25,907,26,659,28,057$ & $8333,8333,8333$ & $\pi-\pi^{*}$ \\
\hline
\end{tabular}

\subsection{Infrared Spectra}

The IR spectral data of NBTCS and its complexes are displayed in Table 3. The N-H stretching vibration for NBTCS was observed as a broad band at $3407 \mathrm{~cm}^{-1}$, this can be seen in Figure 2. However, in $\mathrm{Nd}(\mathrm{III})$ and $\mathrm{Tl}(\mathrm{III})$ complexes, this band disappeared. This suggests that the $\mathrm{N}-\mathrm{H}$ was deprotonated prior to complexation. The IR spectrum of $\mathrm{Nd}(\mathrm{IIII})$ complex as shown in Figure 3 has a broad band at $3399 \mathrm{~cm}^{-1}$, assignable to water of hydration from the metal salt. This was further confirmed by the presence of a sharp peak at $778 \mathrm{~cm}^{-1}$ due to $\mathrm{O}-\mathrm{H}$ bending vibrations. The peak observed around $3046 \mathrm{~cm}^{-1}$ in the $\mathrm{Tl}$ (III) complex was assigned to aromatic $\mathrm{C}-\mathrm{H}$ stretching vibration. The peaks at 1545 and $1465 \mathrm{~cm}^{-1}$ in the ligand were assigned to $\mathrm{C}=\mathrm{N}$ stretching vibration of benzothiazole ring. In the $\mathrm{Nd}(\mathrm{III})$ complex, these shifted to 1589 and $1410 \mathrm{~cm}^{-1}$ while in the Tl(III) complex a single peak at $1548 \mathrm{~cm}^{-1}$ was obtained. This suggest that the $\mathrm{C}=\mathrm{N}$ of benzothiazole was involved in the 
coordination [21,29]. This was further supported by emergence of $\mathrm{M}-\mathrm{N}$ bands between 392 and $420 \mathrm{~cm}^{-1}$. The medium peaks observed between 1154 and $1120 \mathrm{~cm}^{-1}$ in the compounds were assigned to $\mathrm{SO}_{2}$ stretching vibration. The observed decrease in wavenumber of the complexes up to $34 \mathrm{~cm}^{-1}$ suggests coordination through $\mathrm{SO}_{2}$ group. Similar observation has been made in the literature [44]. The $\mathrm{Nd}(\mathrm{III})$ complex showed new band at $1349 \mathrm{~cm}^{-1}$ due to ionic nitrate [45]. A medium band assigned to $\mathrm{M}-\mathrm{O}$ stretch was observed in the $\mathrm{Nd}$ (III) complex at $621 \mathrm{~cm}^{-1}$. The medium bands at 953, 827, 750 and $845 \mathrm{~cm}^{-1}$ in the compounds were assigned to $\mathrm{C}-\mathrm{H}$ bending vibration of substituted benzene ring [46]. The spectra of the compounds are in the Supplementary Materials.

Table 3. Infrared spectral data for NBTCS and its complexes.

\begin{tabular}{|c|c|c|c|c|c|c|c|c|c|c|}
\hline Compound & $\begin{array}{c}v_{\mathrm{N}-\mathrm{H}} \\
\left(\mathrm{cm}^{-1}\right)\end{array}$ & $\begin{array}{c}v_{\mathrm{O}-\mathrm{H}} \\
\left(\mathrm{cm}^{-1}\right)\end{array}$ & $\begin{array}{l}v_{\mathrm{C}-\mathrm{H}} \\
\left(\mathrm{cm}^{-1}\right)\end{array}$ & $\begin{array}{c}v_{\mathrm{C}=\mathrm{N}} \\
\left(\mathrm{cm}^{-1}\right)\end{array}$ & $\begin{array}{c}v_{\mathrm{SO} 2} \\
\left(\mathrm{~cm}^{-1}\right)\end{array}$ & $\begin{array}{c}v_{\mathrm{NO} 3} \text { (ionic) } \\
\left(\mathrm{cm}^{-1}\right)\end{array}$ & $\begin{array}{c}\delta_{\mathrm{C}-\mathrm{H}} \\
\left(\mathrm{cm}^{-1}\right)\end{array}$ & $\begin{array}{c}\delta_{\mathrm{O}-\mathrm{H}} \\
\left(\mathrm{cm}^{-1}\right)\end{array}$ & $\begin{array}{l}v_{M-O} \\
\left(\mathrm{~cm}^{-1}\right)\end{array}$ & $\begin{array}{c}v_{\mathrm{M}-\mathrm{N}} \\
\left(\mathrm{cm}^{-1}\right)\end{array}$ \\
\hline NBTCS & 3407 & - & - & $\begin{array}{l}1545 \\
1465\end{array}$ & 1154 & & $\begin{array}{c}953,827 \\
750\end{array}$ & - & - & - \\
\hline$\left[\mathrm{Nd}(\mathrm{NBTCS})_{2}\left(\mathrm{H}_{2} \mathrm{O}\right)_{2}\right] \mathrm{NO}_{3}$ & $\mathrm{O}_{3}-$ & 3399 & - & $\begin{array}{l}1589 \\
1410\end{array}$ & 1120 & 1349 & - & 778 & 621 & 392 \\
\hline$\left[\mathrm{Tl}(\mathrm{NBTCS})_{2}\right] \mathrm{CH}_{3} \mathrm{COO}$ & - & - & 3142 & 1548 & 1128 & - & 845 & & - & 420 \\
\hline
\end{tabular}

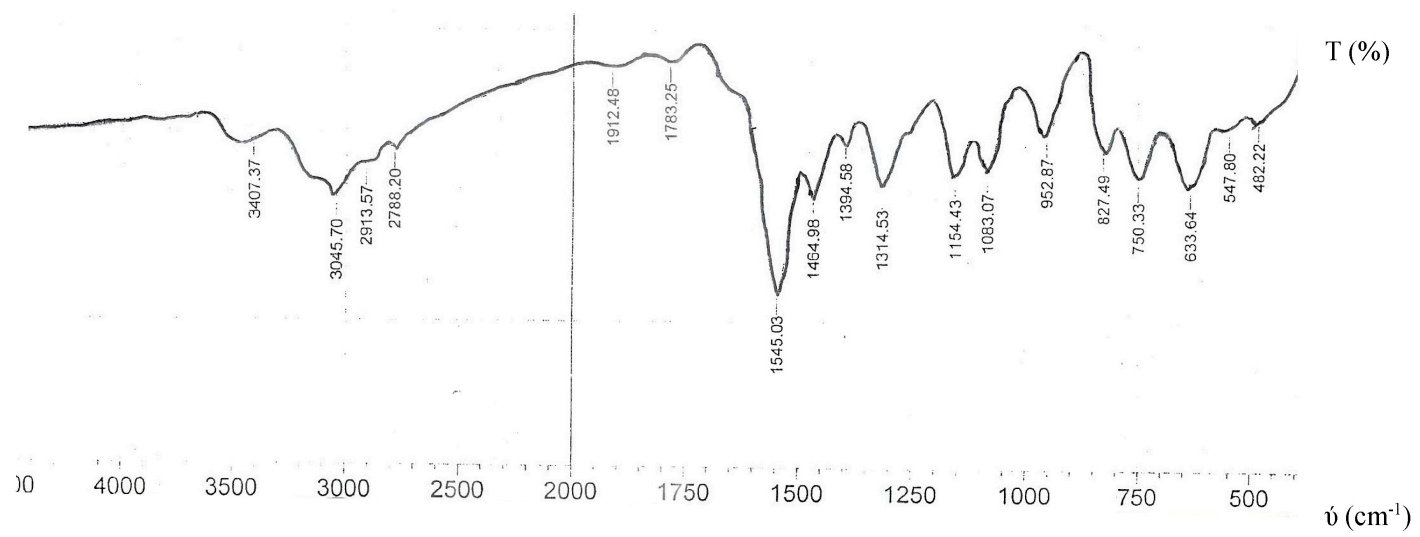

Figure 2. IR spectrum of N-(Benzothiazol-2-yl)-4-chlorobenzenesulphonamide (NBTCS).

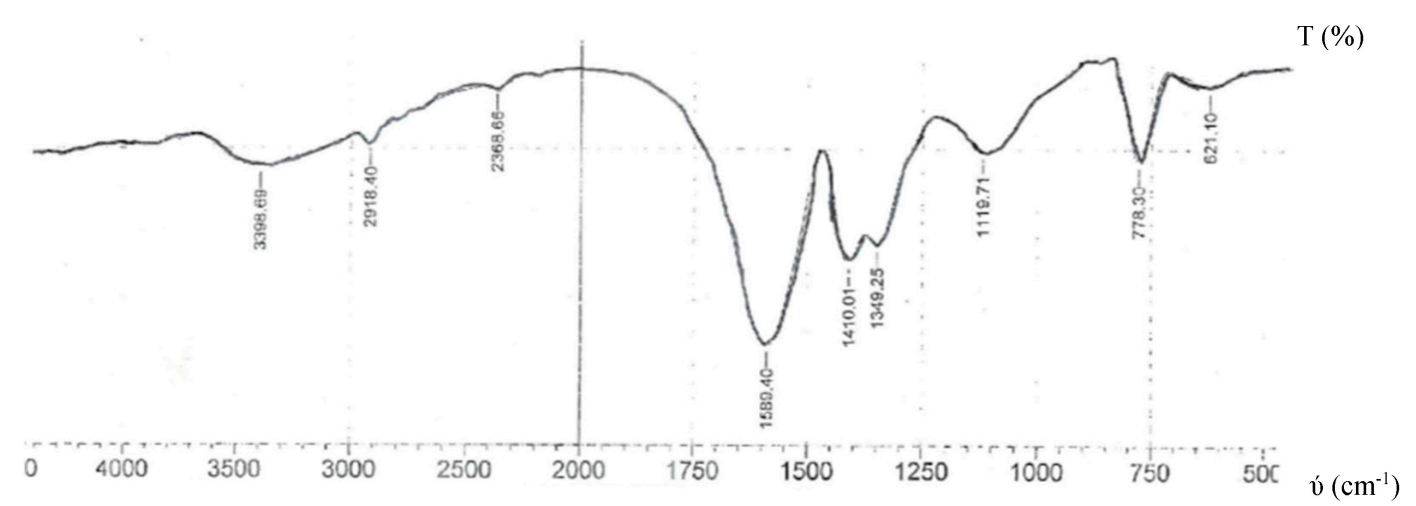

Figure 3. IR spectrum of $\left[\mathrm{Nd}(\mathrm{NBTCS})_{2}\left(\mathrm{H}_{2} \mathrm{O}\right)_{2}\right] \mathrm{NO}_{3}$.

\section{3. ${ }^{1} \mathrm{H}-\mathrm{NMR}$ and ${ }^{13} \mathrm{C}-\mathrm{NMR}$ Spectra}

In the ligand, the peaks obtained in the range 7.20-7.90 ppm are assigned to phenyl and benzothiazole protons. This appeared as a complex multiplet hence separate assignment could not be made. A single peak at $9.35 \mathrm{ppm}$ is also assigned to benzothiazole protons. However, in the complexes, the peaks are clearly separated. In $\left[\mathrm{Nd}(\mathrm{NBTCS})_{2}\left(\mathrm{H}_{2} \mathrm{O}\right)_{2}\right] \mathrm{NO}_{3}$, the peak at $7.15(2 \mathrm{H}, \mathrm{d}) \mathrm{ppm}$ 
and $7.35 \mathrm{ppm}(2 \mathrm{H}, \mathrm{d})$ are assigned to phenyl protons while the peaks at the range of $7.60-8.20 \mathrm{ppm}(4 \mathrm{H}$, $\mathrm{m})$ are assigned to benzothiazole protons. In $\left[\mathrm{Tl}(\mathrm{NBTCS})_{2}\right] \mathrm{CH}_{3} \mathrm{COO}$, the peaks at $7.10(2 \mathrm{H}, \mathrm{d}) \mathrm{ppm}$ and $7.25(2 \mathrm{H}, \mathrm{d}) \mathrm{ppm}$ are assigned to the two chemically equivalent phenyl protons while the peaks at 7.28, $7.47,7.52$ and $7.79 \mathrm{ppm}(4 \mathrm{H}, \mathrm{m})$ are assigned to benzothiazole protons. Similar observation has been made in literature $[21,22,29,44,47]$. The chemical shift due to the $\mathrm{N}-\mathrm{H}$ proton is observed at $13.30 \mathrm{ppm}$ for the ligand but disappeared in the metal complexes indicating its replacement by metal ions. In $\mathrm{Tl}(\mathrm{III})$ complex, peaks at $3.34 \mathrm{ppm}(3 \mathrm{H}, \mathrm{s})$ are assigned to $\mathrm{CH}_{3}$ protons of acetate [22]. The spectra of all the compounds showed a multiplet centered at $2.50 \mathrm{ppm}$ due to DMSO [46].

Figure 4 gives the structure of the ligand showing carbon numbering. ${ }^{13} \mathrm{C}-\mathrm{NMR}$ spectrum of the ligand as shown in Figure 5 has a peak at 115.80 ppm attributed to benzothiazole ring carbon (C1). Peaks assigned to benzothiazole ring carbon (C2) appear at $126.70 \mathrm{ppm}$. Peaks at 139.0 and $140.0 \mathrm{ppm}$ are assigned to benzothiazole ring carbon (C3) and (C4) respectively. Peak at $170.10 \mathrm{ppm}$ is attributed to benzothiazole ring carbon (C5). Peaks at 132.10 and $143.60 \mathrm{ppm}$ are assigned to phenyl ring carbon (C6) and (C9) respectively. The increase in chemical shift of C6 and C9 are due to increase in the electronegativity of the atoms attached to them. $\mathrm{C} 9$ shows a higher value than $\mathrm{C} 6$ because chlorine which is attached to it is more electronegative than sulphur which is attached to C6. Peaks assignable to phenyl ring carbon (C7) and (C8) are observed at 130.30 and $130.60 \mathrm{ppm}$ respectively. Similar observations have been made in literature $[21,22,29,44]$. The ${ }^{13} \mathrm{C}-\mathrm{NMR}$ of the complexes show none of the peaks except for the solvent peak at $40.0 \mathrm{ppm}$. The spectra of the compounds are in the Supplementary Materials.

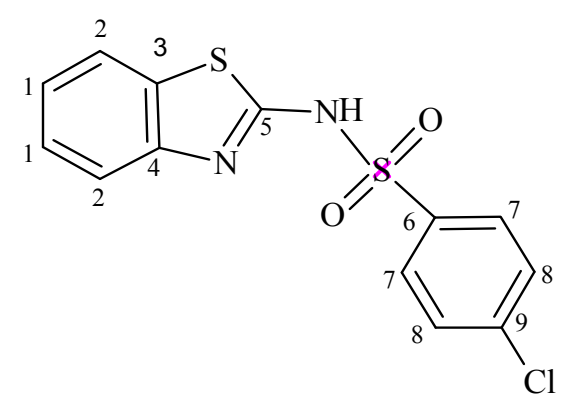

Figure 4. Structure of the ligand showing carbon numbering.

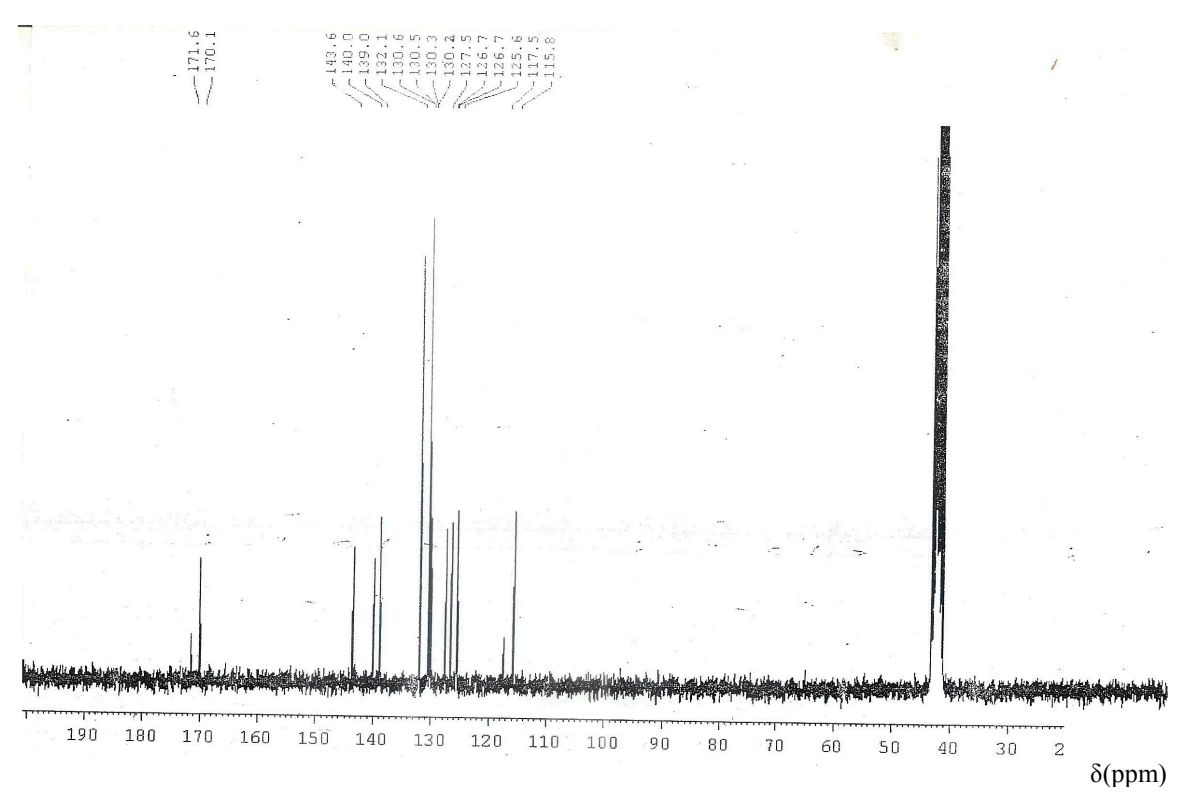

Figure $5 .{ }^{13} \mathrm{C}-\mathrm{NMR}$ spectrum of NBTCS. 
Based on the spectral results, coordination numbers of eight and six were proposed for $\mathrm{Nd}(\mathrm{III})$ and $\mathrm{Tl}(\mathrm{III})$ complexes, respectively, as shown in Figure 6.
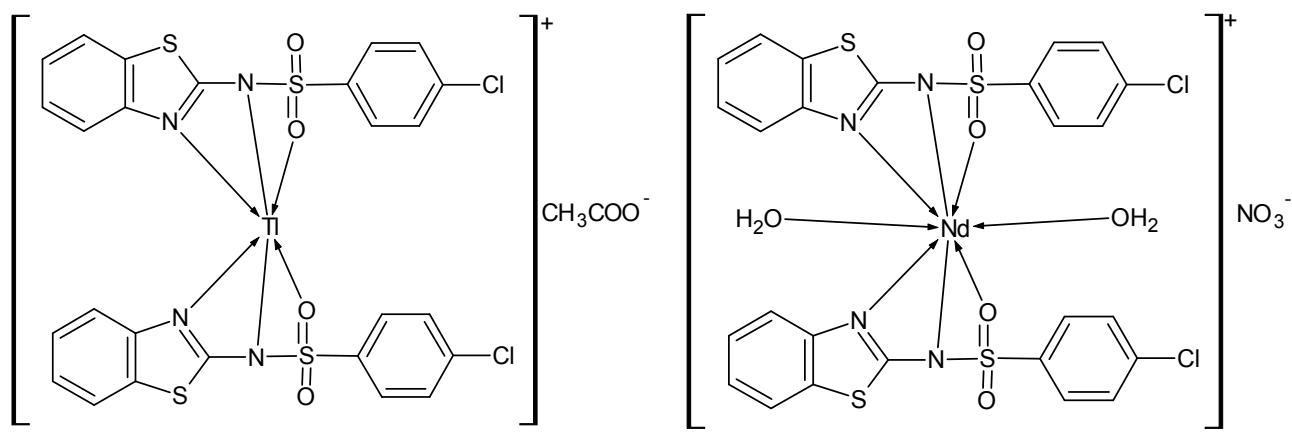

Figure 6. Proposed structure of the complexes.

\subsection{Antibacterial Activity}

The ligand and its complexes were screened in vitro for their antibacterial activity against multi-resistant bacterial strains isolated under clinical conditions namely: Escherichia coli strains (E. coli 6 and E. coli 13), Proteus species, Staphylococcus aureus and Pseudomonas aeruginosa. The antibacterial activities of the compounds were determined using the agar well diffusion method [48]. The inhibitory zone diameter (IZD) and minimum inhibition concentration (MIC) in $\mu \mathrm{g} / \mathrm{mL}$ of the compounds were determined. Co-trimoxazole, ciprofloxacin and gentamicin were used as positive control. The structure of these drugs are shown in Figures 7-9 respectively. Gentamicin belongs to aminoglycosides and their mechanism of action is by inhibition of protein synthesis by preventing the synthesis of nucleic acids (DNA replication or RNA synthesis), thereby blocking transcription. Ciprofloxacin belongs to quinolones and inhibit bacteria growth by preventing DNA synthesis before mitosis [49]. Co-trimoxazole is a sulphonamide, known to prevent the growth of microorganisms by inhibiting folic acid production. Co-trimoxazole contains a fixed combination of sulphamethoxazole and trimethoprim.<smiles>COc1cc(Cc2cnc(N)nc2N)cc(OC)c1OC</smiles>

Trimethoprim<smiles>Cc1cc(NS(=O)(=O)c2ccc(N)cc2)no1</smiles>

Sulphamethoxazole

Figure 7. Structure of co-trimoxazole.<smiles>O=C(O)c1cn(C2CC2)c2cc(N3CCNCC3)c(F)cc2c1=O</smiles>

Figure 8. Structure of ciprofloxacin. 
<smiles>CN[C@H]1[C@@H](O)[C@@H](O[C@@H]2[C@@H](N)C[C@@H](N)[C@H](O[C@@H]3OC([C@H](C)N)CC[C@H]3N)[C@H]2O)OC[C@]1(C)O</smiles>

Figure 9. Structure of gentamicin.

The result of the IZD (Table 4) shows that the metal complexes exhibit higher antibacterial activity against the microorganisms relative to the ligand. It was also observed that the ligand did not inhibit the growth of $S$. aureus and P. aeruginosa. Likewise, the thallium complex had no effect on P. aeruginosa. The increase in antibacterial activity of the metal chelates might be due to the effect of the metal ion on the normal cell process. Chelation reduces the polarity of the metal ion because of partial sharing of its positive charge with donor groups and the $\pi$-electron delocalization over the whole chelate ring. Such chelation could enhance the lipophilic character of the central metal atom, which subsequently favours its permeation through the lipid layers of the cell membrane [50]. From the MIC values (Table 5), it is observed that the synthesized compounds are more active against Escherichia coli strains 6 and 13 relative to the standard drugs, since the lower the MIC value, the more effective the antibacterial activity of the drug. However, Ciprofloxacin has a higher antibacterial activity against S. aureus and Proteus species compared to the compounds. It can also be inferred from Table 5 that the synthesized compounds have better antibacterial activity against the microorganisms screened relative to Gentamicin and Co-trimoxazole.

Table 4. Antibacterial activity of NBTCS, $\left[\mathrm{Nd}(\mathrm{NBTCS})_{2}\left(\mathrm{H}_{2} \mathrm{O}\right)_{2}\right] \mathrm{NO}_{3}$ and $\left[\mathrm{Tl}(\mathrm{NBTCS})_{2}\right] \mathrm{CH}_{3} \mathrm{COO}$.

\begin{tabular}{cccccc}
\hline \multicolumn{7}{c}{ IZD Values $\mathbf{( m m )}$} \\
\hline Compounds & E. coli 6 & E. coli 13 & S. aureus & P. aeruginosa & Proteus species \\
\hline NBTCS & 13 & 10 & 0 & 0 & 12 \\
{$\left[\mathrm{Nd}(\mathrm{NBTCS})_{2}\left(\mathrm{H}_{2} \mathrm{O}\right)_{2}\right] \mathrm{NO}_{3}$} & 15 & 14 & 17 & 12 & 16 \\
{$\left[\mathrm{Tl}(\mathrm{NBTCS})_{2}\right] \mathrm{CH}_{3} \mathrm{COO}$} & 12 & 12 & 15 & 0 & 12 \\
\hline
\end{tabular}

IZD: inhibitory zone diameter.

Table 5. MIC values of the compounds and standard drugs.

\begin{tabular}{cccccc}
\hline \multicolumn{7}{c}{ MIC Values $(\mu \mathrm{g} / \mathrm{mL})$} \\
\hline Compounds & E. coli 6 & E. coli 13 & S. aureus & P. aeruginosa & Proteus species \\
\hline NBTCS & 3.16 & 4.57 & 0.00 & 0.00 & 3.39 \\
{$\left[\mathrm{Nd}(\mathrm{NBTCS})_{2}\left(\mathrm{H}_{2} \mathrm{O}\right)_{2}\right] \mathrm{NO}_{3}$} & 1.78 & 2.19 & 1.45 & 3.31 & 1.26 \\
{$\left[\mathrm{Tl}(\mathrm{NBTCS})_{2}\right] \mathrm{CH}_{3} \mathrm{COO}$} & 3.47 & 3.47 & 1.26 & 0.00 & 3.47 \\
Ciprofloxacin & 20.00 & 20.00 & 0.63 & 10.00 & 0.16 \\
Gentamicin & 100.00 & 100.00 & 2.50 & 20.00 & 5.00 \\
Co-trimoxazole & 100.00 & 100.00 & 50.00 & 170.00 & 30.00 \\
\hline
\end{tabular}




\section{Materials and Methods}

\subsection{Materials}

All the reagents and solvents used were of analytical grade and were used as supplied unless otherwise stated. The melting point of the ligand and the complexes were determined using a Gallenkamp melting point apparatus (Weiss Technik, Loughborough, UK) and were uncorrected. Electronic spectra (in ethanol) were recorded on a UV-2500PC series spectrophotometer (SHIMADZU, Tokyo, Japan). The FTIR spectra were performed using FTIR-8400S Spectrophotometer (SHIMADZU), in the range $4500-200 \mathrm{~cm}^{-1}$ using $\mathrm{KBr}$. The ${ }^{1} \mathrm{H}$ - and ${ }^{13} \mathrm{C}-\mathrm{NMR}$ of the ligand were recorded on Bruker Spectrospin 250(Bruker, Billerica, MA, USA) using DMSO while the elemental analysis was done using Euro EA 3000 Dual CHNS Analyzer (Eurovector S.P.A, Zurich, Switzerland) both at the Department of Chemistry, University of Mauritius.

\subsection{Synthesis of N-(Benzothiazol-2-yl)-4-chlorobenzenesulphonamide (NBTCS)}

To a solution of 2-aminobenzothiazole $(3.0 \mathrm{~g} ; 20 \mathrm{mmol})$ in acetone $(15 \mathrm{~mL})$ was added 4-chlorobenzenesulphonylchloride $(4.24 \mathrm{~g} ; 20 \mathrm{mmol})$ with stirring. The mixture was refluxed for $45 \mathrm{~min}$ at $130{ }^{\circ} \mathrm{C}$. A white precipitate was formed, which was recrystallized from absolute ethanol, dried and stored in a desiccator over anhydrous $\mathrm{CaCl}_{2}$. This is shown in Scheme 1 . The yield was $40.83 \%$ and the melting point $220-222{ }^{\circ} \mathrm{C}$.

\subsection{Synthesis of [N-(Benzothiazol-2-yl)-4-chlorobenzenesulphonamide] Neodymium(III) Complex, $\left[\mathrm{Nd}(\mathrm{NBTCS})_{2}\left(\mathrm{H}_{2} \mathrm{O}\right)_{2}\right] \mathrm{NO}_{3}$}

To a solution of $N$-(benzothiazol-2-yl)-4-chlorobenzenesulphonamide (1.62 $\mathrm{g} ; 5.17 \mathrm{mmol})$ in acetone $(10 \mathrm{~mL})$ was added aqueous solution of neodymium(III) nitrate pentahydrate, $\mathrm{Nd}\left(\mathrm{NO}_{3}\right)_{3} \cdot 5 \mathrm{H}_{2} \mathrm{O}$ $(1.05 \mathrm{~g} ; 1.37 \mathrm{mmol})$. This was refluxed for $1 \mathrm{~h}$ at $120{ }^{\circ} \mathrm{C}$ during which a yellow precipitate was formed. The resulting yellow precipitate formed was filtered, dried in a stream of air and stored in a desiccator over anhydrous $\mathrm{CaCl}_{2}$. The yield was $32.24 \%$ and the melting point is $245-247^{\circ} \mathrm{C}$.

\subsection{Synthesis of [N-(Benzothiazol-2-yl)-4-chlorobenzenesulphonamide] Thallium(III) Complex, $\left[\mathrm{Tl}(\mathrm{NBTCS})_{2}\right] \mathrm{CH}_{3} \mathrm{COO}$}

To a solution of $N$-(benzothiazol-2-yl)-4-chlorobenzenesulphonamide (1.62 $\mathrm{g} ; 5.17 \mathrm{mmol})$ in acetone $(10 \mathrm{~mL})$ was added aqueous solution of thallium(III) acetate, $\mathrm{C}_{6} \mathrm{H}_{9} \mathrm{O}_{6} \mathrm{Tl}(0.95 \mathrm{~g} ; 1.14 \mathrm{mmol})$. This was refluxed for $1 \mathrm{~h}$ at $120^{\circ} \mathrm{C}$ during which a brown precipitate was formed. The resulting brown precipitate formed was filtered, dried in a stream of air and stored in a desiccator over anhydrous $\mathrm{CaCl}_{2}$. The yield was $34.97 \%$ and the melting point is $235-237^{\circ} \mathrm{C}$.

\subsection{Antibacterial Activity}

The inhibitory activity of the ligand and its metal complexes were carried out on the following microorganisms: Escherichia coli strains (E. coli 6 and E. coli 13), Proteus species, Staphylococcus aureus and Pseudomonas aeruginosa. The bacteria strains used were isolated from clinical conditions. The method used was the agar well-diffusion Technique [46]. Mueller-Hinton agar plates were inoculated with $0.1 \mathrm{~mL}$ of $3 \mathrm{~h}$ broth culture of the test microorganisms. Using a cork borer, wells $(7 \mathrm{~mm}$ in diameter and $2.5 \mathrm{~mm}$ deep) were bored into the inoculated agar. Fresh solutions $(1000 \mu \mathrm{g} / \mathrm{mL})$ of all the synthesized compounds were prepared in DMSO and $50 \mu \mathrm{L}$ of each compound was delivered into the wells. Wells containing $1000 \mu \mathrm{g} / \mathrm{mL}$ of ciprofloxacin, gentamicin and co-trimoxazole in DMSO were used as positive controls. The plates were incubated at $37^{\circ} \mathrm{C}$ for $24 \mathrm{~h}$ and assessment of antibacterial activity was based on the measurement of the diameter of inhibition zone (IZD) around the wells.

The minimum inhibitory concentrations (MIC) of the test compounds were determined using the same method. Two-fold serial dilutions of test compound were made in DMSO. The final concentration of the compounds ranged from 250 to $0.625 \mu \mathrm{g} / \mathrm{mL}$. Inoculated plates were incubated at $37^{\circ} \mathrm{C}$ for $24 \mathrm{~h}$ 
and observed for presence of visible growth. The minimum inhibition concentration was determined as the value of the lowest concentration that completely suppressed the growth of the microorganisms.

\section{Conclusions}

NBTCS and its neodymium(III) and thallium(III) complexes were synthesized. Based on the UV, IR and NMR spectral studies and elemental analysis, a coordination number of eight was proposed for neodymium(III) complex and six for thallium(III) complex. The antibacterial activity revealed that the synthesized compounds have better antibacterial activity against the microorganisms screened relative to gentamicin and co-trimoxazole. The low MIC values observed for NBTCS and its complexes indicate the potency of these compounds as antibacterial agents. This serves as a marker in drug design, hence these compounds should be screened for in vivo antibacterial activity and the lethal dose $\left(\mathrm{LD}_{50}\right)$ determined.

Supplementary Materials: The following are available online at: http://www.mdpi.com/1420-3049/22/2/153/s1, FTIR Spectra, electronic spectra, ${ }^{1} \mathrm{H}-\mathrm{NMR}$ and ${ }^{13} \mathrm{C}-\mathrm{NMR}$ of the ligand and complexes.

Acknowledgments: The authors acknowledge the facilities from their respective universities and the comments to anonymous reviewers. Ibrahim Abdulrazak Al-Swaidan (I.A.A.-S.) and Ponnadurai Ramasami (P.R.) extend their appreciation to the International Scientific Partnership Program ISPP at King Saud University for funding this research work through ISPP\# 0070.

Author Contributions: L.N.O. conceived, designed and supervised the experiment. U.S.O. performed the experiment. I.A.A.-S. and P.R. carried out the elemental analysis and ${ }^{1} \mathrm{H}$ - and ${ }^{13} \mathrm{C}-\mathrm{NMR}$ spectroscopy of the synthesized compounds. A.E.O. contributed in proofreading of the entire work and made professional input. C.J.E. contributed in proofreading of the entire work. U.S.O. wrote the paper.

Conflicts of Interest: The authors declare no conflict of interest.

\section{References}

1. Yun, M.-K.; Wu, Y.; Li, Z.; Zao, Y.; Waddell, M.B.; Ferreira, A.M.; Lee, R.E.; Bashford, D.; White, S.W. Catalysis and Sulpha Drugs Resistance in Dihydropteroate Synthase. Science 2012, 335, 1110-1114. [CrossRef] [PubMed]

2. Bhat, M.A.; Imran, M.; Khan, S.A.; Siddioui, N. Biological activities of Sulfonamides. Indian J. Pharm. Sci. 2005, 67, 151-159.

3. Guar, A.; Gupta, R.K.; Shrivastava, B. Colorimetric Estimation of Sulphacetamide Sodium in bulk and in Formulation. Indian J. Pharm. Sci. 2007, 69, 464-467. [CrossRef]

4. Genç, Y.; Özkanca, R.; Bekdemir, Y. Antimicrobial activity of some sulphonamide derivatives on clinical isolates of Staphylococus aureus. Ann. Clin. Microbiol. Antimicrob. 2008, 7, 17-22. [CrossRef] [PubMed]

5. Ozbek, N.; Katircioğlu, H.; Karacan, N.; Baykal, T. Synthesis, characterization and antimicrobial activity of new aliphatic sulfonamide. Bioorg. Med. Chem. 2007, 15, 5105-5109. [CrossRef] [PubMed]

6. Kaur, I.P.; Smitha, R.; Aggarwal, D.; Kapil, M. Acetazolamide: Future Perspective in Topical Glaucoma Therapeutics. Int. J. Pharm. 2002, 248, 1-14. [CrossRef]

7. Arnold, P.J. The Chemistry of metal Complexes with Selenolate and Tellurolate Ligands. Prog. Inorg. Chem. 1995, 43, 353-417.

8. Ghorab, M.M.; Ragab, F.A.; Hamed, M.M. Design, synthesis and anticancer evaluation of Novel tetrahydroquinoline derivatives containing sulfonamide moiety. Eur. J. Med. Chem. 2009, 44, 4211-4217. [CrossRef] [PubMed]

9. El-Sayed, N.S.; El-Bendary, E.R.; El-Ashry, S.M.; El-Kerdawy, M.M. Synthesis and antitumora ctivity of new sulphonamide derivatives of thiadiazolo[3,2-a]pyrimidines. Eur. J. Med. Chem. 2011, 46, 3714-3720. [CrossRef] [PubMed]

10. Ma, T.; Fuld, A.D.; Rigas, J.R.; Hagey, A.E.; Gordon, G.B.; Dmitrovsky, E.; Dragnev, K.H. A Phase I Trial and in vitro Studies Combining ABT-751 with Carboplatin in Previously Treated Non-Small Cell Lung Cancer Patients. Chemotherapy 2012, 58, 321-329. [CrossRef] [PubMed] 
11. Borne, R.F.; Peden, R.L.; Waters, I.W.; Weiner, M.; Jordan, R.; Coats, E.A. Anti-inflammatory activity of para-substituted N-benzenesulfonyl derivatives of anthranilic acid. J. Pharm. Sci. 1974, 63, 615-617. [CrossRef] [PubMed]

12. Kennedy, J.; Thorley, M. Pharmaceutical Substances, 3rd ed.; Kleeman, A., Engel, J., Kutscher, B., Reichert, D., Eds.; Thieme: Stuttgart, Germany, 1999; p. 27.

13. Kanda, Y.; Kawanishi, Y.; Oda, K.; Sakata, T.; Mihara, S.; Asakura, K.; Kanemasa, T.; Ninomiya, M.; Fujimoto, M.; Kanoike, T. Synthesis and structure-activity relationships of potent and orally active sulfonamide ETB selective antagonists. Bioorg. Med. Chem. 2001, 9, 897-907. [CrossRef]

14. De Clercq, E. New developments in anti-HIV chemotherapy. Curr. Med. Chem. 2001, 8, 1543-1572. [CrossRef] [PubMed]

15. Dekker, M. Protease Inhibitors in AIDS Therapy; Ogden, R.C., Flexner, C.W., Eds.; NY Bagel: New York, NY, USA, 2001; p. 112.

16. Kent, M. Advanced Biology; Oxford University Press: Oxford, UK, 2000; p. 46.

17. Brackett, C.C.; Singh, H.; Block, J.H. Likelihood and Mechanisms of Cross-allergenicity between Sulfonamide antibiotics and other drugs containing a Sulfonamide functional group. Pharmacotherapy 2004, 24, 856-870. [CrossRef] [PubMed]

18. Slatore, C.G.; Tilles, S. Sulfonamide hypersensitivity. Immunol. Allergy Clin. N. Am. 2004, 24, 477-490. [CrossRef] [PubMed]

19. Lawrence, H.R.; Kazi, A.; Luo, Y.; Kendig, R.; Ge, Y.; Jain, S.; Daniel, K.; Santiago, D.; Guida, W.C.; Sebti, S.M. Synthesis and biological evaluation of naphthoquinone analogs as a novel class of proteasome inhibitors. Bioorg. Med. Chem. 2010, 18, 5576-5592. [CrossRef] [PubMed]

20. Obasi, L.N.; Okoye, C.O.B.; Ukoha, P.O.; Anaga, A.O. Syntheses, Characterization, and Antimicrobial Screening of $\mathrm{N}$-(benzothiazol-2-yl) benzenesulphonamide and its $\mathrm{Cu}(\mathrm{I}), \mathrm{Ni}(\mathrm{II}), \mathrm{Mn}(\mathrm{II}), \mathrm{Co}(\mathrm{II})$, and $\mathrm{Zn}$ (II) Complexes. E-J. Chem. 2012, 9, 2354-2370. [CrossRef]

21. Obasi, L.N.; Okoye, C.O.B.; Ukoha, P.O.; Chah, K.F. Synthesis, Characterization and Antimicrobial Screening of $\mathrm{N}$-(benzothiazol-2-yl)-2,5-dichlorobenzenesulphonamide and its $\mathrm{Cu}(\mathrm{I}), \mathrm{Ni}(\mathrm{II}), \mathrm{Mn}$ (II), $\mathrm{Co}$ (III) and $\mathrm{Zn}$ (II) Complexes. Asian J. Chem. 2013, 25, 2199-2207.

22. Obasi, L.N.; Okoye, C.O.B.; Ukoha, P.O.; Chah, K.F. Synthesis, characterization and Antimicrobial Screening of $\mathrm{N}$-(benzothiazol-2-yl)-4-methylbenzenesulphonamide and its $\mathrm{Cu}(\mathrm{I}), \mathrm{Ni}(\mathrm{II}), \mathrm{Mn}(\mathrm{II}), \mathrm{Co}(\mathrm{II})$ and $\mathrm{Zn}$ (II) Complexes. Asian J. Chem. 2013, 25, 2369-2376.

23. Caira, M.R. Molecular complexes of sulfonamides. 2.1:1 complexes between drug molecules: Sulfadimidineacetylsalicylic acid and sulfadimidine-4-aminosalicylic acid. J. Chem. Crystallogr. 1992, 22, 193-200. [CrossRef]

24. Chohan, H.Z.; Mahmood-ul-Hassan; Khan, K.M.; Supuran, C.T. In-vitro antibacterial, antifungal and cytotoxic properties of Sulfonamide-derived Schiff's bases and their metal complexes. J. Enzym. Inhib. Med. Chem. 2005, 20, 183-188. [CrossRef] [PubMed]

25. Obaleye, J.A.; Adediji, J.F.; Adebayo, M.A. Synthesis and Biological Activities on Metal Complexes of 2,5-diamino-1,3,4-thiadiazole derived from Semicarbazide Hydrochloride. Molecules 2011, 16, 5861-5874. [CrossRef] [PubMed]

26. Issa, R.M.; Azim, S.A.; Khedr, A.M.; Draz, D.F. Synthesis, Characterization, thermal and antimicrobial studies of binuclear metal complexes of Sulfa-guanidine Schiff bases. J. Coord. Chem. 2009, 62, 1859-1870. [CrossRef]

27. Narang, K.; Gupta, J.K. Copper(II) acetate and Picrate Complexes of Sulfa drugs. Transit. Met. Chem. 1977, 2, 83-86. [CrossRef]

28. Jitianu, A.; Llies, M.A.; Scozzafava, A.; Supuran, C.T. Synthesis and Carbonic Anhydrase Inhibitory activities of 5-Benzoylamido- and 5-(3-nitrobenzoylamido)-1,3,4-thiadiazole-2-sulfonamide and their metal complexes. Main Group Met. Chem. 1997, 20, 151-156. [CrossRef]

29. Oruma, U.S.; Ukoha, P.O.; Asegbeloyin, J.N. Synthesis, Characterization and Biological Studies of S-1,3-Benzothiazol-2-ylthiophene-2-carbothioate and Its $\mathrm{Ce}(\mathrm{IV})$ and $\mathrm{Nd}(\mathrm{III})$ Complexes. Asian J. Chem. 2014, 26, 7622-7626.

30. Rinehart, J.D.; Long, J.R. Slow Magnetic Relaxation in Homoleptic Trispyrazolylborate Complexes of Neodymium(III) and Uranium(III). Dalton Trans. 2012, 14, 13572-13574. [CrossRef] [PubMed]

31. Khorasani-Motlagh, M.; Norozifar, M.; Niroomand, S.; Saffari, J. Synthesis and Spectroscopy Studies of new Neodymium(III) Complexes with Cyanamide Derivatives as N-Donor Ligands. J. Iran. Chem. Soc. 2010, 4, 807-813. [CrossRef] 
32. Kostova, I.; Manolov, I.; Momekov, G. Cytotoxic Activity of new Neodymium(III) Complexes of Bis-Coumarins. Eur. J. Med. Chem. 2004, 39, 765-775. [CrossRef] [PubMed]

33. Romanov, A.S.; Muratov, D.V.; Timofeeva, T.V.; Kudinov, A.R. Triple-decker complex $\mathrm{CpCo}\left(\mu-\mathrm{C}_{3} \mathrm{~B}_{2} \mathrm{Me}_{5}\right)$ $\mathrm{Rh}\left(\mathrm{C}_{2} \mathrm{H}_{4}\right)_{2}$ : Synthesis, structure and bonding. Inorg. Chim. Acta 2014, 415, 120-123. [CrossRef]

34. Kumar, S.; PalSharma, R.; Saini, A.; Venugopalan, P.; Starynowicz, P. Synthesis, characterization, single crystal X-ray, structure determination and packing analysis of thallium(I)anthracene-9-carboxylate, $\left[\mathrm{Tl}_{4}\left(\mathrm{H}_{2} \mathrm{O}_{2}\right)\right.$ (anthracene-9-carboxylate) $\left.{ }_{4}\right]$. J. Mol. Struct. 2015, 1079, 291-297. [CrossRef]

35. Sivagurunathan, G.S.; Ramalingam, K.; Rizzoli, C. Nanothallium(III)sulfide from dithiocarbamate precursors: Synthesis. Single crystal X-ray structures and characterization. Polyhedron 2013, 65, 316-321. [CrossRef]

36. Gharib, F.; Feizabadi, M.; Soltani, L. Equilibrium studies of thallium(I) complexes with cytidine 5 -monophosphate in different aqueous solutions of methanol. J. Mol. Liquids 2013, 182, 64-69. [CrossRef]

37. Rana, S.; Sharma, N.; Ojha, H.; Shivkumar, H.G.; Sultana, S.; Sharma, R.K. p-Tertbutylcalix[4]arenenanoemulsion: Preparation, characterization and comparative evaluation of its decontamination efficacy against Technetium-99m, Iodine 131 and Thallium-201. Colloids Surf. B Biointerfaces 2014, 117, 114-121. [CrossRef] [PubMed]

38. Mimouni, M.; Khardli, F.Z.; Warad, I.; Ahmad, M.; Mubarak, M.S.; Sultana, S.; Hadda, T.B. Antimicrobial Activity of Naturally occurring Antibiotics Monensin, Lasalocid and their Metal Complexes. J. Mater. Environ. Sci. 2014, 5, 207-214.

39. Marc, A.; Daniel, H. Crystal structure of the thallium salt of the antibiotics Grisorixin. J. Chem. Soc. Chem. Commun. 1972, 175-176. [CrossRef]

40. Rutkowski, J.; Brzezinski, B. Structures and Properties of Naturally Occurring Polyether Antibiotics. BioMed Res. Int. 2013, 2013, 162513. [CrossRef] [PubMed]

41. Imran, A.; Waseem, A.W.; Kishwar, S. Empirical Fomulae to Molecular Structures of Metal Complexes by Molar Conductance. Synth. React. Inorg. Metal-Organ. Nano-Met. Chem. 2013, 43, 1162-1170.

42. Lekha, L.; Raja, K.K.; Rajagopal, G.; Easwaramoorthy, D. Synthesis, Spectroscopic Characterization and antibacterial studies of lanthanide(III) Schiff base complexes containing N, O donor atoms. J. Mol. Struct. 2014, 1056-1057, 307-313. [CrossRef]

43. Mamdouh, S.M.; Ekram, A.K.; Ahmad, M.R.; Yousry, M.G.; Amr, S. Spectral, electrical conductivity and biological activity properties of some new azopyrimidine derivatives and their complexes. Spectrochim. Acta A 2007, 67, 669-677.

44. Obasi, L.N.; Ukoha, P.O.; Chah, K.F. Synthesis, Spectroscopic Characterization and Antimicrobial Screening of $N$-(thiazol-2-yl)-4-chlorobenzenesulphonamide and its $\mathrm{Ni}(\mathrm{II})$ and $\mathrm{Co}(\mathrm{II})$ Complexes. J. Chem. Soc. Niger. 2011, 36, 102-109.

45. Dawood, Z.F.; Al-Moula, F.J.A. Preparation and Characterization of Cr(III) and Cu(II) Complexes With Mixed Ligand Containing Isatinazine and Semicarbazones. J. Univ. Anbar Pure Sci. 2009, 3, 21-31.

46. Robert, M.; Francis, X.; David, J. Spectrometric Identification of Organic Compounds, 7th ed.; John Wiley \& Sons, Inc.: Hoboken, NJ, USA, 2005; pp. 89, 95-97, 200.

47. Ummathur, M.B.; Sayudevi, P.; Krishnankutty, K. Schiff bases of 3-[2-(1,3-benzothiazol-2-yl)hydrazinylidene] pentane-2,4-dione with aliphatic diamines and their metal complexes. J. Argent. Chem. Soc. 2009, 97, 31-39.

48. Collins, C.; Lynes, P.; Grange, J. Microbiological Methods, 7th ed.; Butterwort-Heinemann Ltd.: Oxford, UK, 1995; pp. 175-190.

49. Galbraith, A.; Bullock, S.; Manias, E.; Hunt, E.; Richard, A. Fundamentals of Pharmacology. An Applied Approach for Nursing and Health, 2nd ed.; Pearson Education Limited: Harlow, UK, 2007; pp. 723-725, 741.

50. Jadhav, S.M.; Munde, A.S.; Shankarwar, S.G.; Patharkar, V.R.; Shelke, V.A.; Chondhekar, T.K. Synthesis, Potentiometric, Spectral Characterization and Microbial Studies of Transition Metal Complexes with Tridentate Ligand. J. Korean Chem. Soc. 2010, 54, 515-522. [CrossRef]

Sample Availability: Not available.

(C) 2017 by the authors; licensee MDPI, Basel, Switzerland. This article is an open access article distributed under the terms and conditions of the Creative Commons Attribution (CC-BY) license (http://creativecommons.org/licenses/by/4.0/). 